\title{
Long noncoding RNA expression profiles in sub-lethal heat-treated hepatoma carcinoma cells
}

Qingsong Deng ${ }^{\dagger}$, Shihan Chen ${ }^{\dagger}$, Chunchuan Fu, Jiayun Jiang, Mengda Zou, Yunhua Tan, Xiaofei Wang, Feng Xia, Kai Feng ${ }^{*}$, Kuansheng $\mathrm{Ma}^{*}$ and Ping Bie

\begin{abstract}
Background: Sub-lethal heat treatment characterizes a transition zone of radiofrequency ablation (RFA) which explains hepatocellular carcinoma (HCC) residual cancer occurrence in this area after RFA treatment. The biochemistry of residual cancer cell recurrence is poorly understood, but long noncoding RNAs (IncRNAs) may have aberrant expression that is associated with diverse cancers. Thus, we measured IncRNA gene expression in sub-lethally heat-treated HCC cells using microarray.

Method: Differentially expressed IncRNA and mRNA were measured with an Agilent Human IncRNA + mRNA Array V4.0 (4×180 K format) containing 41,000 IncRNAs and 34,000 mRNAs. Bioinformatics analysis was used to assess differentially expressed IncRNA and mRNA. Seven IncRNA and seven mRNA were validated by qRT-PCR analysis in HCC cells.

Results: Genome-wide IncRNA and mRNA expression data in sub-lethal heat-treated SMMC-7721 HCC cells 558 IncRNA and 250 mRNA were significantly up-regulated and 224 IncRNA and 1031 mRNA down-regulated compared to normal cultured SMMC-7721 cells. We demonstrated for the first time that ENST00000570843.1, ENST00000567668.1, ENST00000582249.1, ENST00000450304.1, TCONS_00015544, ENST00000602478.1, TCONS_00001266 and ARC, IL12RB1, HSPA6 were upregulated, whereas STAT3, PRPSAP1, MCU, URB2 were down-regulated in sub-lethally heat-treated HCC cells.
\end{abstract}

Conclusions: IncRNA expression data in sub-lethally heat-treated HCC cells will provide important insights about IncRNAs' contribution to HCC recurrence after RFA treatment.

Keywords: Long noncoding RNA, Hepatocellular carcinoma, Sub-lethal heat treatment, Residual cancer, Radiofrequency ablation

\section{Background}

Liver cancer is the second leading cause of cancer death for men in less developed countries. In more developed countries, it is the sixth leading cause of cancer death among men [1] and hepatocellular carcinoma (HCC) is the most prevalent and malignant type of liver cancer. Radiofrequency ablation (RFA) is commonly used to treat nonresectable and small liver tumors $(\leq 3 \mathrm{~cm})$ and may provide tumor clearance and increase quality of life.

\footnotetext{
*Correspondence: fengkai7688@hotmail.com; makuansheng@vip.sina.com
${ }^{\dagger}$ Equal contributors

*Correspondence: fengkai7688@hotmail.com; makuansheng@vip.sina.com
${ }^{\dagger}$ Equal contributors

Institute of Hepatobiliary Surgery, Southwest Hospital, Third Military Medical University, Chongqing 400038, China
}

(c) The Author(s). 2017 Open Access This article is distributed under the terms of the Creative Commons Attribution 4.0 International License (http://creativecommons.org/licenses/by/4.0/), which permits unrestricted use, distribution, and reproduction in any medium, provided you give appropriate credit to the original author(s) and the source, provide a link to the Creative Commons license, and indicate if changes were made. The Creative Commons Public Domain Dedication waiver (http://creativecommons.org/publicdomain/zero/1.0/) applies to the data made available in this article, unless otherwise stated.

However, clinical research results indicate that local recurrence after RFA of liver tumors varies between 2 to $60 \%$ [2-4], which is greater than after liver resection. The literature is almost unanimous that local hepatic tumor recurrence after RFA is sooner than after liver resection, why this occurs is not clear.

RFA temperature distribution effectively divides the treatment area into an application, central, transition, and reference zones. For the application and central zones, $60{ }^{\circ} \mathrm{C}$ is applied and causes immediate necrosis [5]. Transition zone temperature is $42-60{ }^{\circ} \mathrm{C}$, which is insufficient to kill tumor cells, so some cells survive and can form subsequent tumors. The reference area has no effect on tumor cells. 
After RFA, HCC cell biological behavior is modified, and sub-lethal RFA may actually increased malignant transformation of HCC [6] and facilitate rapid progression of residual hepatic VX2 carcinoma [7]. Also, rapid progression of residual tumors via hypoxia inducible factor-1 $\alpha(\mathrm{HIF}-1 \alpha) /$ vascular endothelial growth factor A (VEGFA) pathways can occur and epithelial-mesenchymal transition (EMT) markers have been reported to be expressed at these recurrence sites after RFA treatment [8]. Also, insufficient RFA promotes EMT of HCC cells [9] and malignancy [10]. After insufficient RFA, tumorassociated endothelial cells have enhanced angiogenesis and invasiveness of residual HCC [11], and this may promote tumor angiogenesis via HIF-1 $\alpha$ /VEGFA pathway [12]. Incomplete RFA stimulates proliferation of residual renal carcinoma cells [13] and enhances invasiveness and metastasis of residual HCC cancers [14].

Long noncoding RNA (lncRNA) is generally defined as a transcript larger than 200 nucleotides that lacks protein-coding functions. Recently, lncRNAs have been shown to have critical regulatory roles in cancer biology, including genetic imprinting, immune response, tumorigenesis, cellular development, and metabolism $[15,16]$. HCC lncRNA expression measured with microarray confirmed that hundreds of lncRNAs were abnormally expressed in HCC tissues [17]. Furthermore, invasionand metastasis-related IncRNA of HCC have also been identified [18]. However, the role of lncRNA in biological behavioral changes in residual HCC cells in the transition zone of RFA treatment is still unclear.

In the present work, cultured SMMC-7721 cells were subjected to hyperthermia $\left(50{ }^{\circ} \mathrm{C}\right)$ for $10 \mathrm{~min}$ to mimic the transition zone produced by RFA, and this is an accepted model at this time [10,11]. Then, we measured changes in lncRNA expression in HCC cells and estimated the biological significance of these lncRNAs.

\section{Methods \\ Cell culture}

Human SMMC-7721, HepG2, and MHCC97-H HCC cells were obtained from the Cell Bank of the Shanghai Institutes for Biological Sciences, Chinese Academy of Sciences (Shanghai, China). Cells were maintained in high-glucose Dulbecco's modified Eagle's medium (DMEM) (GIBCO, Invitrogen, Australia) supplemented with $10 \%$ fetal bovine serum (FBS) (GIBCO, Invitrogen) and $1 \%$ penicillin-streptomycin (GIBCO, Invitrogen) at $37{ }^{\circ} \mathrm{C}$ in a $5 \% \mathrm{CO}_{2}$ atmosphere.

\section{Sub-lethal heat treatment}

SMMC-7721, HepG2, and MHCC97-H cells were sublethally heated $\left(50{ }^{\circ} \mathrm{C}\right)$ for $10 \mathrm{~min}$. Heat treatments were carried out by sealing the culture bottle with Parafilm, and submerging the plates in a water bath $(\mathrm{HH} \cdot \mathrm{W} 21$.
600S, Shanghai, China) set at $50{ }^{\circ} \mathrm{C}$ and returned to the incubation chamber (Series II Water Jacket, ThermoScientific, Waltham, MA) for $24 \mathrm{~h}$ at $37{ }^{\circ} \mathrm{C}$. Three independent experiments were performed.

\section{RNA extraction}

Total RNA was extracted from sub-lethally heattreated HCC cells using RNAiso Plus Reagent (TaKaRa, Dalian, China) according to the manufacturer's instructions. RNA quantification and quality were assured with a NanoDrop ND-2000 spectrophotometer (ThermoScientific). RNA integrity and gDNA contamination were confirmed with agarose gel electrophoresis (Additional file 1: Figure S1).

\section{Microarray analysis}

Sample preparation and microarray hybridization and assay were performed by CapitalBio Corporation (Beijing, China). Briefly, RNA was purified with mirVana miRNA Isolation Kit (Ambion, Austin, TX) according to the manufacture's protocol. cDNA labeled with a fluorescent dye (Cy5 and $\mathrm{Cy} 3-\mathrm{dCTP})$ was produced using Eberwine's linear RNA amplification method and subsequent enzymatic reaction as described [19] with improvements using a CapitalBio cRNA Amplification and Labeling Kit (CapitalBio) for greater yields of labeled cDNA. cRNA amplification and labeling is depicted in Additional file 2: Figure S2. IncRNA + mRNA array data were analyzed for summarization, normalization and quality control with GeneSpring software V13.0 (Agilent). To select differentially expressed genes, we used threshold values of $\geq 2$ and $\leq-2$-fold changes and a Benjamini-Hochberg corrected $p$ value were $<0.05$ (multiple testing, Benjamini-Hochberg method). Data were Log2-transformed and median centered using genes and the Adjust Data function of CLUSTER 3.0 software then analyzed with hierarchical clustering with average linkages. Finally, we performed tree visualization using Java Treeview (Stanford University School of Medicine, Stanford, CA).

\section{Construction of the IncRNA-mRNA gene co-expression network}

The IncRNA-mRNA co-expression network was constructed based on the correlation between differentially expressed lncRNAs and mRNAs. For each gene pair, a Pearson correlation coefficient was calculated and significant correlation pairs were selected to construct the network. lncRNAs and mRNAs with coefficients $\geq 0.99$ were selected for network design using the open-source bioinformatics software Cytoscape. In a network analysis, a degree centrality is defined as the links one node has with other nodes. A degree is the simplest and most important measures of a gene centrality within a 


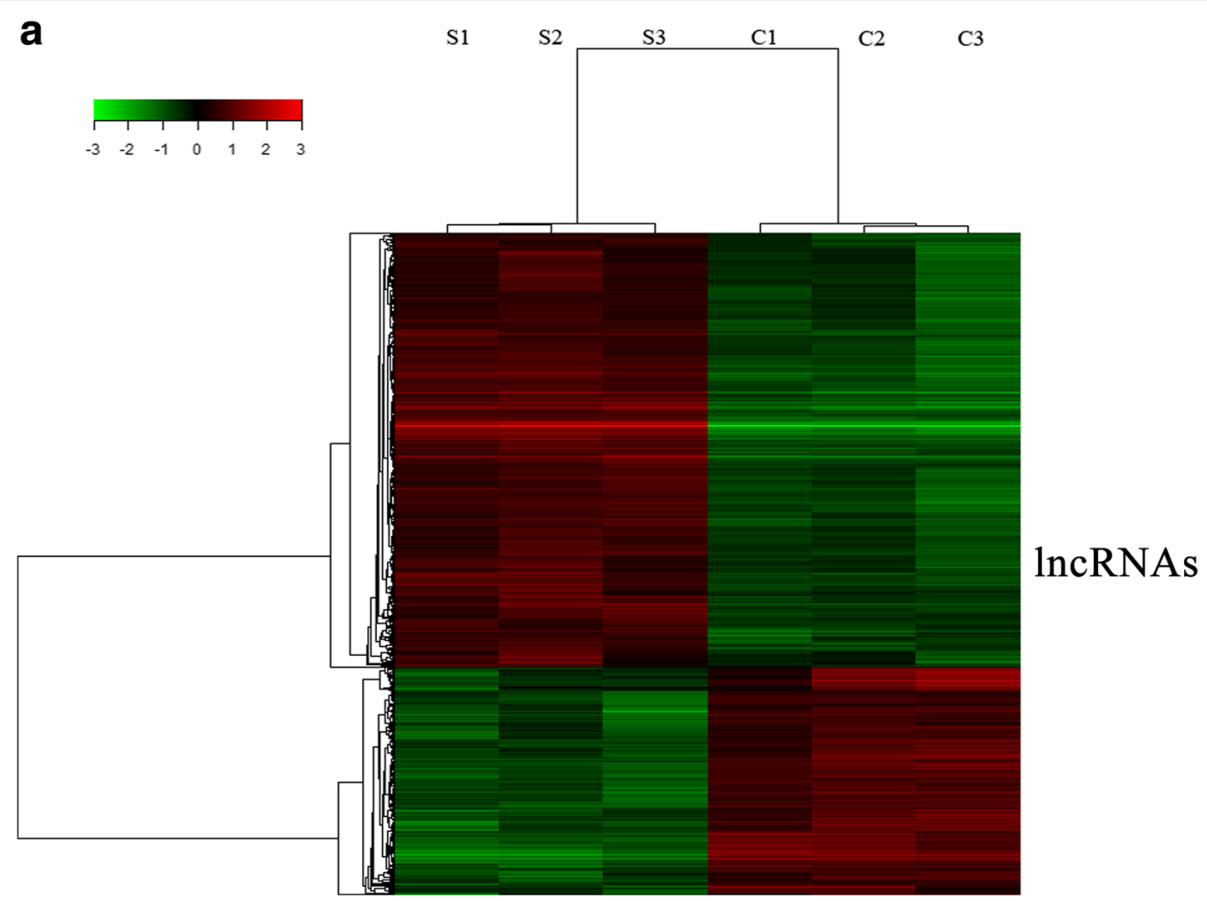

b

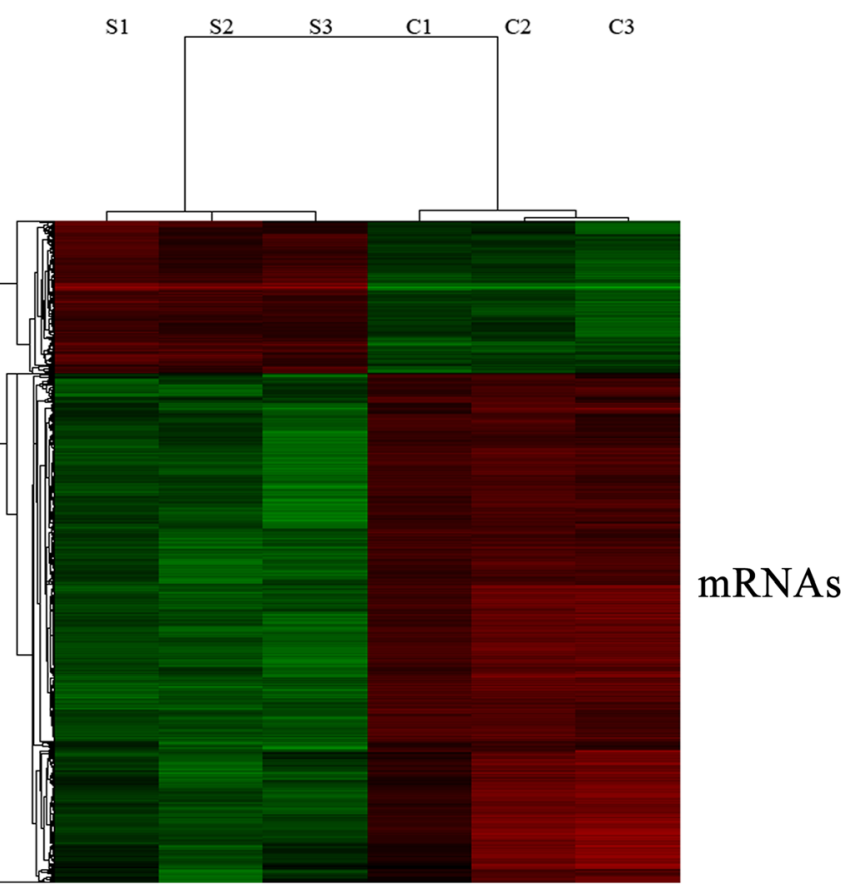

Fig. 1 Heat maps of differential expression and hierarchical clustering of IncRNAs (a) and mRNAs (b) in sub-lethally heat-treated HCC cells and untreated HCC cells. S sub-lethal heat treatment; C Control (Normal culture)

network and this establishes relative importance [20]. A yellow ellipse represents selected seven up-regulated lncRNAs and a green ellipse represents mRNAs. Red lines represent positive correlations and blue lines represent negative correlations.
Gene ontology and pathway analysis

KOBAS 2.0 (KEGG Orthology Based Annotation System) was used to perform GO and pathway analysis. Its purpose is to identify significantly enriched pathways and diseases for a set of genes or proteins, 
using pathway and disease information from multiple databases. In the present study, $p<0.05$ was a threshold to eliminate pathways related to sub-lethally heat treated HCC cells.

\section{Liver specific IncRNA analysis}

We downloaded liver-specific lncRNA data from deepbase v2.0 (http://rna.sysu.edu.cn/deepBase/heatmap_lncRNA_Table.php?SClade $=$ mammal\&SOrganism $=$ hg $19 \&$ SSource=deepBase2study_humanBody). We screened highly enriched (5.766 to 0.332) and less enriched ( -2.98 to $0.445)$ hepatic lncRNAs according to the expression mean normalization ( $\log 2(\mathrm{FPKM})$-mean). Then, we identified and compared hepatic lncRNAs with low expression in the liver to hepatic lncRNAs highly expressed in sublethally heat-treated HCC cells to determine which lncRNAs were modified.

\section{Quantitative reverse transcription PCR (qRT-PCR) validation}

Total RNA was reverse-transcribed using a PrimeScript RT reagent Kit with gDNA Eraser (Perfect Real Time) (RR047A, TaKaRa, Dalian, China) with a GeneAmp PCR system 2700 (Applied Biosystems, Singapore). Real-time PCR amplification was used to measure lncRNA and mRNA with SYBR Premix Ex Taq II (RR820A, TaKaRa, Dalian, China) with a CFX96 Real-Time System (C1000 Thermal Cycler, Bio-Rad, Singapore) according to the manufacturer's protocol. Amplification conditions were $95{ }^{\circ} \mathrm{C}$ for $30 \mathrm{~s}$, followed by 40 cycles of $95^{\circ} \mathrm{C}$ for $5 \mathrm{~s}$ and $60{ }^{\circ} \mathrm{C}$ for $30 \mathrm{~s}$ or $95{ }^{\circ} \mathrm{C}$ for $5 \mathrm{~s}, 55^{\circ} \mathrm{C}$ for $30 \mathrm{~s}$ and $72{ }^{\circ} \mathrm{C}$ for $30 \mathrm{~s}$, with a final extension at $65{ }^{\circ} \mathrm{C}$ for $5 \mathrm{~s}$. Primers used are shown in Additional file 3: Tables S1 and Additional file 4: S2. GAPDH was used as a control. lncRNA and mRNA were calculated using the formula $2^{-\Delta \Delta \mathrm{Ct}}$, as previously reported [21].

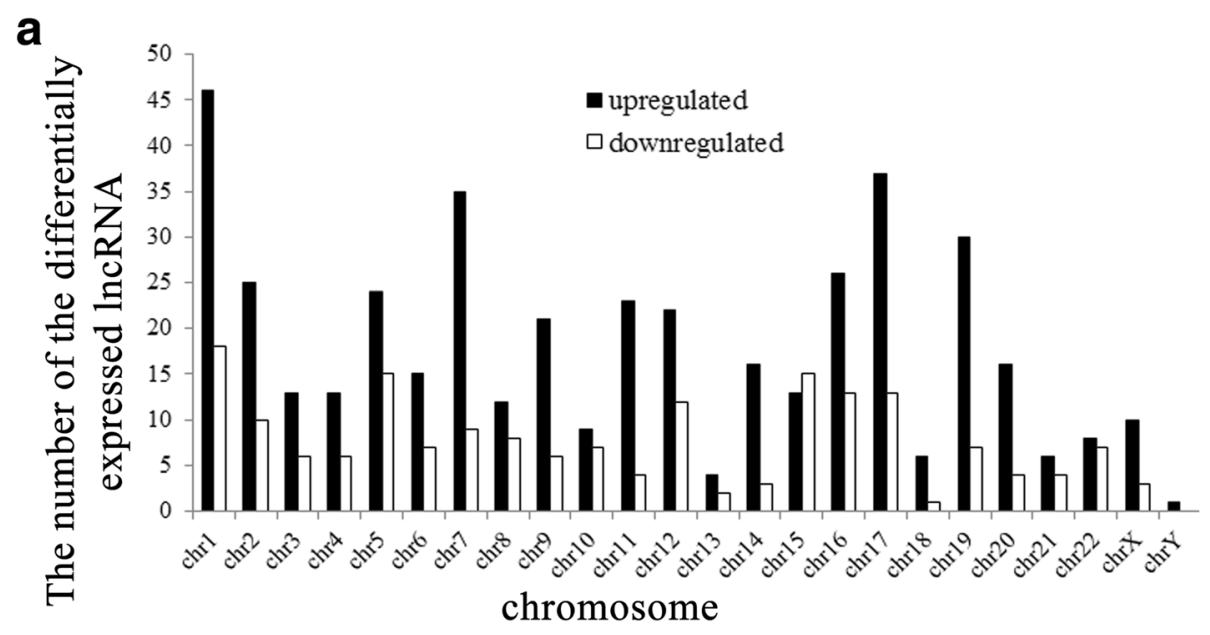

b

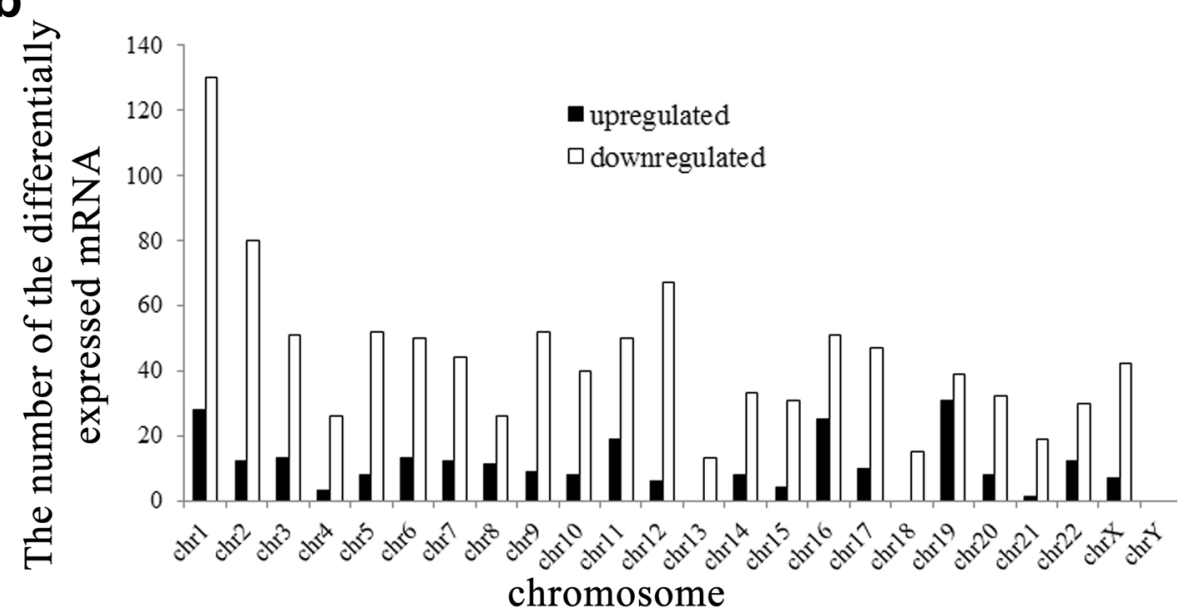

Fig. 2 Up- and down-regulated IncRNA (a) and mRNA (b) on each chromosome in comparison between sub-lethally heat-treated HCC cells and untreated HCC cells 


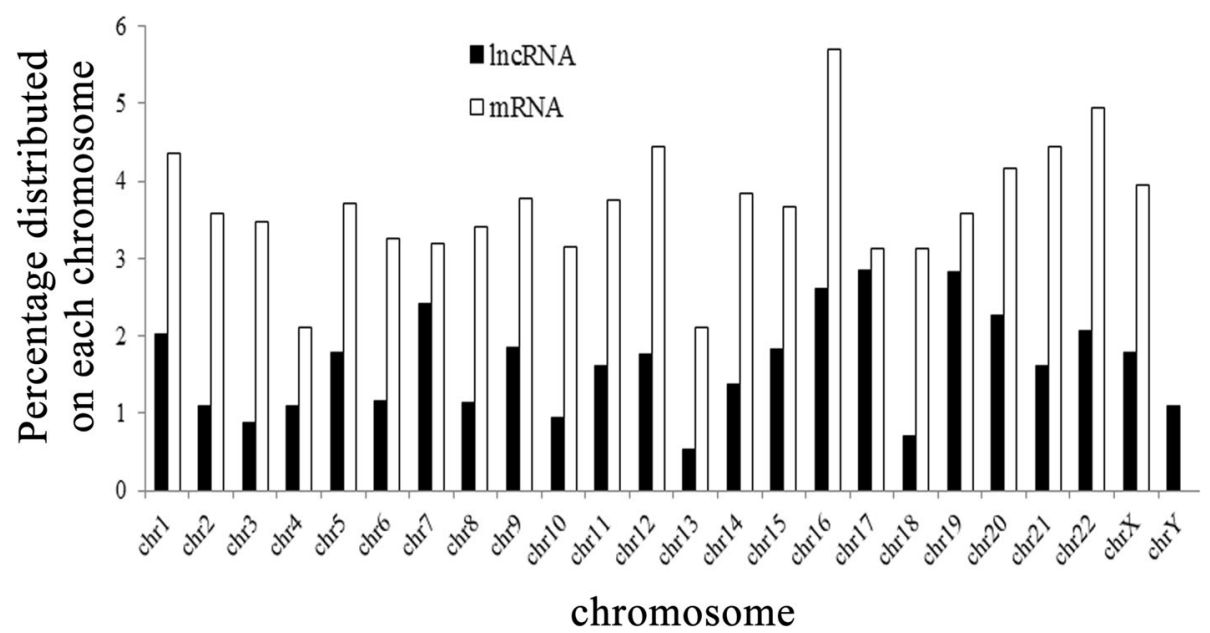

Fig. 3 Distribution of significantly differentially expressed IncRNAs and mRNAs on each chromosome in comparisons between sub-lethally heat-treated HCC cells and untreated HCC cells

\section{Statistical analysis}

All assays were repeated a minimum of three times. Data were analyzed using SPSS 17.0 software. All quantitative data were expressed as means \pm standard deviations (SD). Gene expression in sub-lethally heat-treated HCC cells was compared to non-treated HCC cells. A Student's t-test was used to compare data between the two groups $(p<0.05$ was considered a statistically significant difference).

\section{Results}

\section{Expression profile of IncRNA and mRNA in sub-lethally heat-treated HCC cells}

To identify lncRNA and mRNA modified by sub-lethal heat treatment in $\mathrm{HCC}$, we applied RFA $\left(50{ }^{\circ} \mathrm{C}\right)$ to SMMC-7721 HCC cells continuously for $10 \mathrm{~min}$ to simulate the RFA transition zone.

Fold-changes (treated vs non-treated HCC cells) and $p$ (Corr)-values were calculated from normalized expression data. Using microarray analysis (Fig. 1), we identified 782 lncRNAs and 1,281 mRNAs to be significantly differentially expressed in sub-lethally heat-treated HCC cells (foldchange $\geq 2.0, p($ Corr $)<0.05)$. Among these, 558 lncRNA and 250 mRNA were consistently upregulated in sub-lethally heat-treated HCC cells, and 224 lncRNA and 1,031 mRNA were consistently downregulated (Additional file 5: Table S3). IncRNA XR_428946.1 expression (fold-change $=227.8$ ) was significantly upregulated, but expression of XR_243720.2 (foldchange =15.3) was dramatically downregulated. These lncRNA may play important roles in the occurrence and development of residual hepatocellular carcinoma cells after insufficient RFA treatment. Activity-regulated cytoskeleton-associated protein $(A R C)$ expression (fold-change $=130.2$ ) was significantly upregulated, and expression of chemokine (C-X-C motif) ligand $1(C X C L 1)$ (foldchange $=26.0)$ was dramatically downregulated.

Differentially expressed lncRNAs and mRNAs in sublethally heat-treated HCC cells were not distributed equally on all chromosomes. Distribution pattern analysis of differentially expressed lncRNAs and mRNAs on chromosomes confirmed that chromosome 1 (chr1) had the most differentially expressed lncRNAs and mRNAs, chromosome Y (chrY) had the least differentially expressed lncRNAs and mRNAs (Fig. 2).

We found that chromosome 1 has the most differentially expressed lncRNAs and mRNAs, but due to many genes on chromosome 1, the proportion of differentially expressed genes was not the greatest. The most differentially expressed lncRNA were on chromosome 17 , whereas mRNA was on chromosome 16. Chromosome 16 has the greatest fraction of differentially expressed lncRNA and mRNA (Fig. 3).

\section{IncRNA classification and subgroup analysis}

Analysis of the genomic context of lncRNAs that were changed in sub-lethally heat-treated HCC cells may predict or identify their functional role. Therefore, we analyzed

Table 1 Overview of the subgroups of differentially expressed IncRNAs in sub-lethally heat-treated HCC cells

\begin{tabular}{llllll}
\hline Expression & Sense IncRNAs & Antisense IncRNAs & Intronic IncRNAs & Divergent IncRNAs & Intergenic IncRNAs \\
\hline Upregulated & 6 & 154 & 12 & 34 & 188 \\
Downregulated & 4 & 81 & 10 & 10 & 59 \\
\hline
\end{tabular}




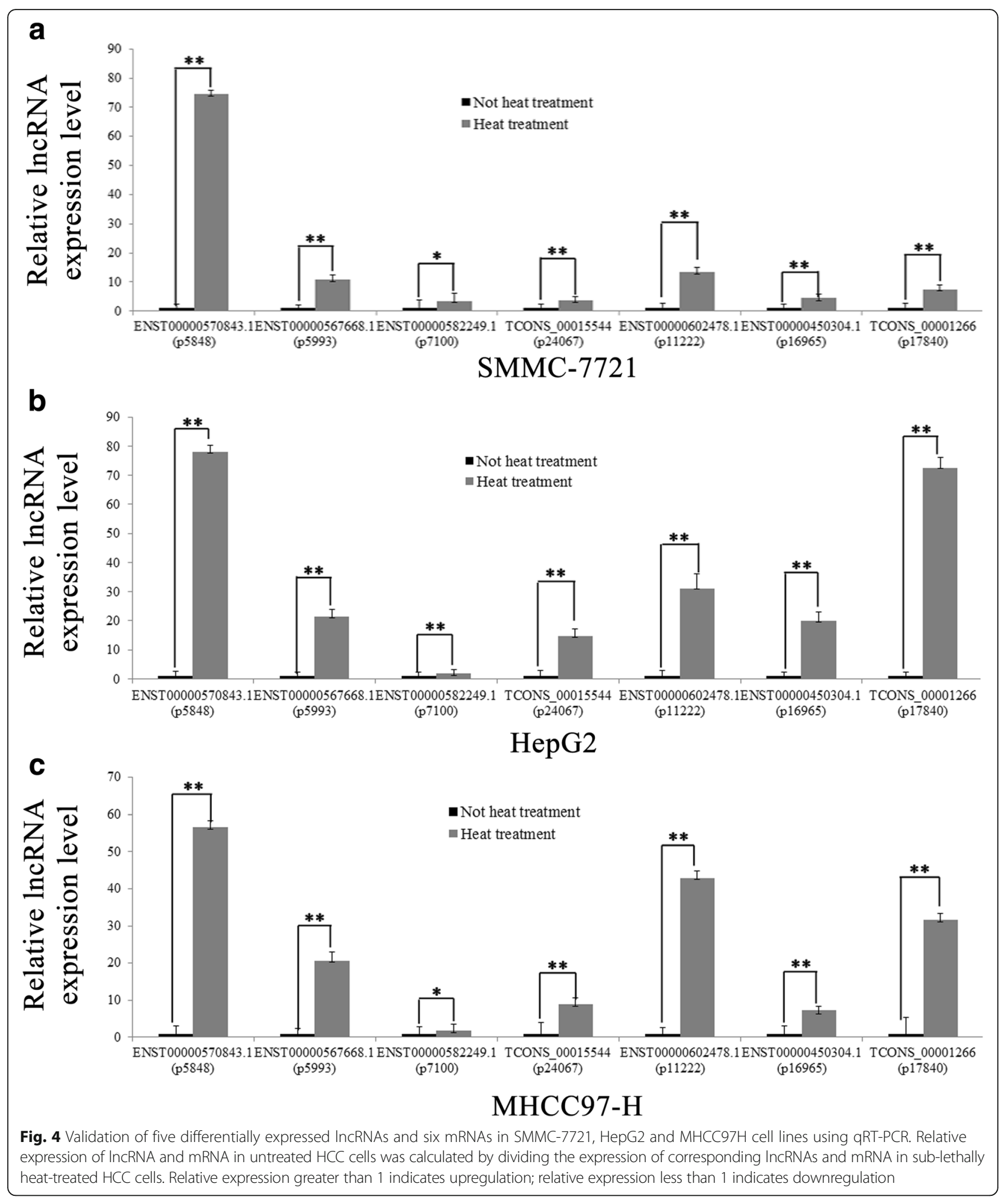

associations between lncRNAs and mRNAs to identify putative functional relationships, categorizing these as sense, antisense, intronic, divergent or intergenic types.
The most differentially expressed lncRNA are intergenic types of lncRNA. Data for these relationships appear in Tables 1 and Additional file 6: S4 and Additional file 7: S5. 


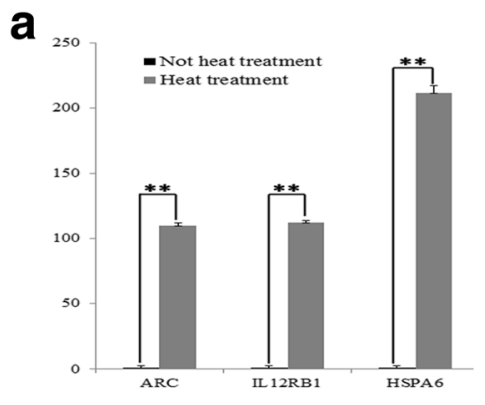

SMMC-7721

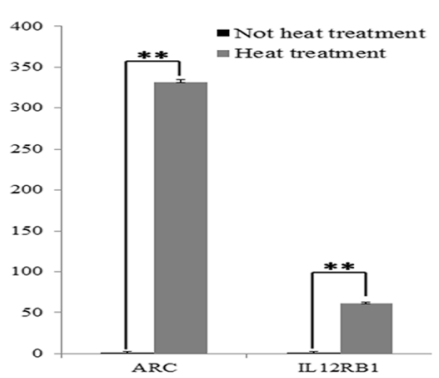

HepG2

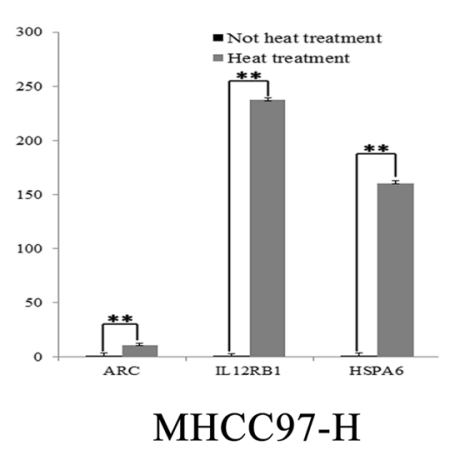

b

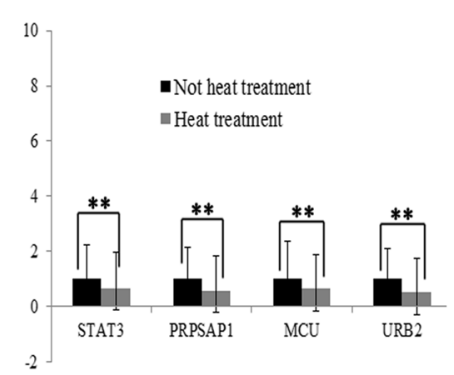

SMMC-7721

C

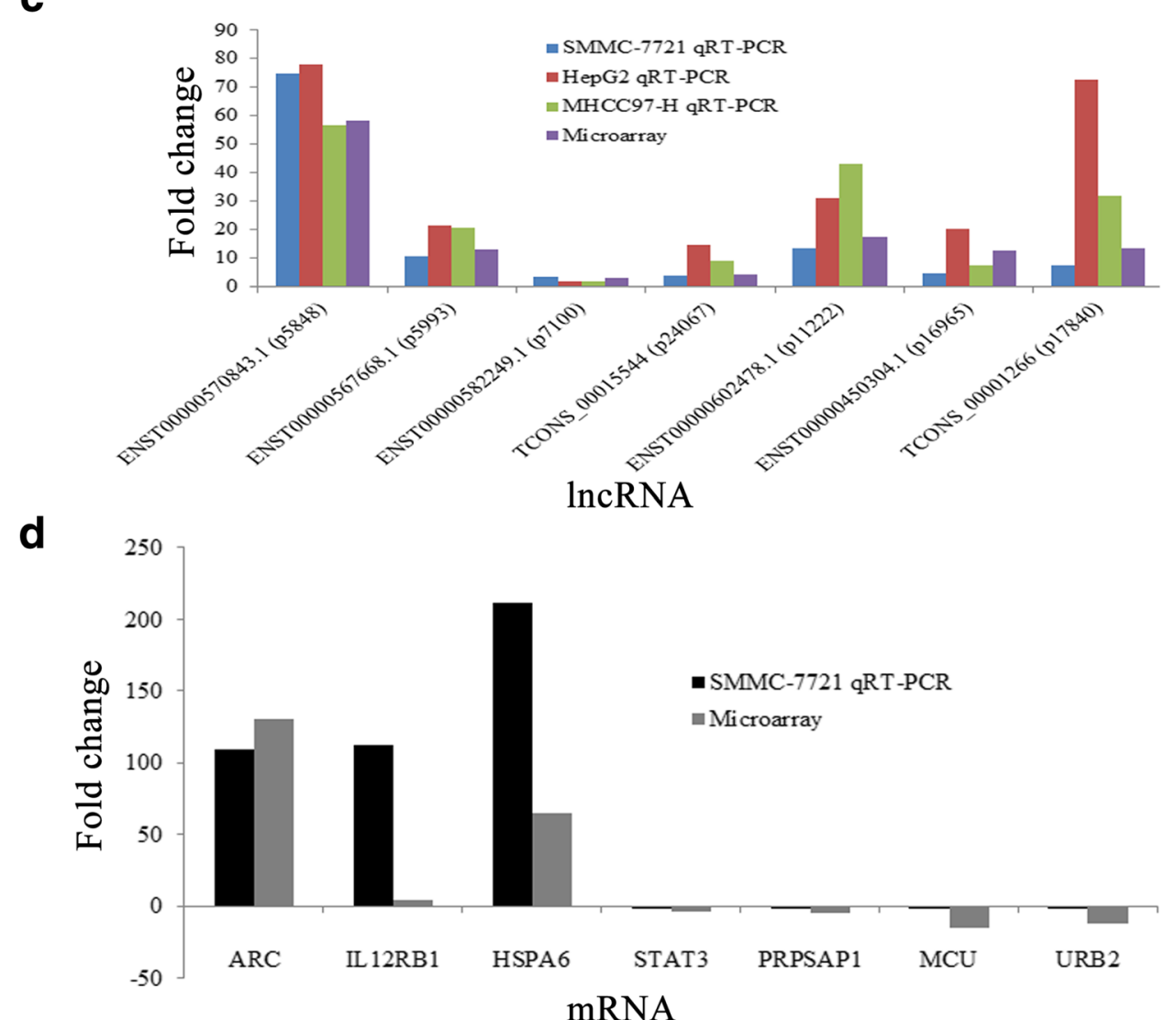

d

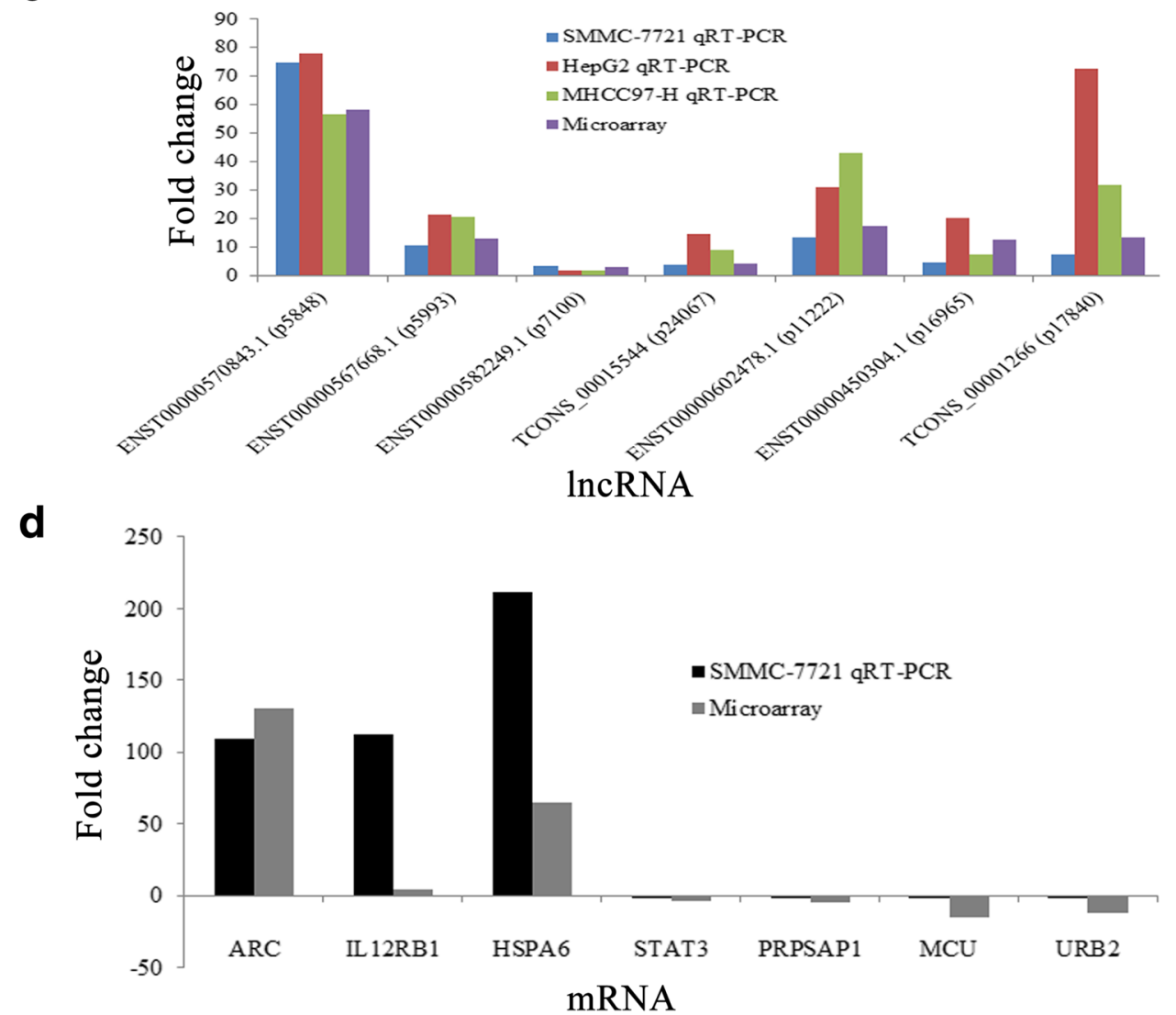

Fig. 5 (See legend on next page.)

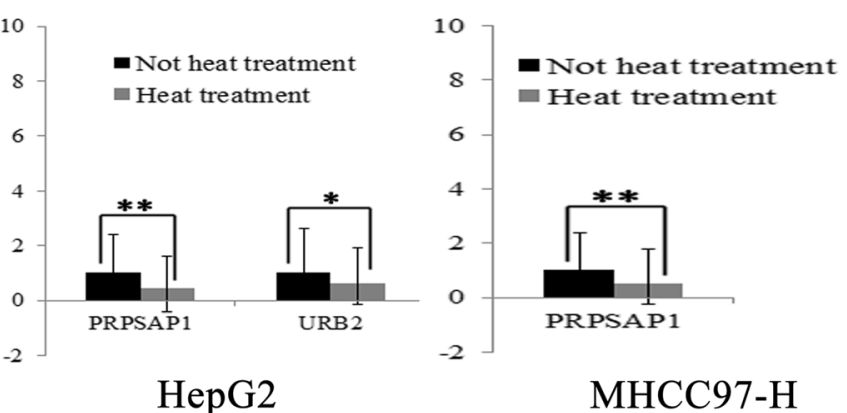


(See figure on previous page.)

Fig. 5 Co-expression network of five upregulated IncRNA from comparisons between sub-lethally heat-treated HCC cells and untreated HCC cells, with differentially expressed mRNA. Correlation $>0.99$ or $\leq 0.99$ and $p<0.05$ were recognized as co-expression. Yellow ellipse represents five up-regulated IncRNAs; green ellipse represents mRNA. Red lines: positive correlation, blue lines: negative correlation. Node size indicates node degrees (number of neighbors)

\section{Liver specific IncRNA analysis}

We found 560 liver-specific highly expressed and 400 under expressed IncRNAs in the deepbase, and compared it with microarray data, and 3 lncRNA had modified expression after sub-lethal heat treatment. Also, two lncRNA(GAS5 and PVT1) were up-regulated and one was (OIP5-AS1) downregulated. These data appear in Additional file 8: Table S6. These three lncRNA may have a role in the biochemistry of residual cancer cell recurrence after RFA treatment.

\section{qRT-PCR analysis of IncRNA and mRNA expression}

According to fold-differences, co-expression, and liverspecific lncRNA analysis, we initially identified many candidate lncRNA and mRNA for validation. Seven lncRNAs (ENST00000570843.1, ENST00000567668.1, EN ST00000582249.1, ENST00000450304.1, TCONS_00015 544, ENST00000602478.1, TCONS_00001266 and seven mRNAs (ARC, IL12RB1, HSPA6, STAT3, PRPSAP1, MCU, URB2) were examined with qRT-PCR (Fig. 4, Fig. 5a, b) and Tables 2 and 3 depict data regarding their characteristics. IncRNA qRT-PCR and microarray data were consistent (Fig. 5c, d), but mRNA expression changes in HepG2 and MHCC97-H cell lines were not consistent with that in SMMC-7721 cells. For example, HSPA6 gene expression in HepG2 cells was not statistically significantly different between the heat treatment and no treatment groups. (Fig. 5a, b)

\section{Construction of the IncRNA-mRNA co-expression network} To understand the correlation between differentially expressed lncRNAs and mRNAs in sub-lethally heattreated HCC cells, we constructed a IncRNA-mRNA co-expression network but the data were too numerous, so we selected seven lncRNAs and used qRT-PCR validation to create a network diagram (Fig. 6, Additional file
9: Table S7). We identified seven pairs of co-expressed lncRNAs and mRNAs composed of 548 mRNA (37.61\% [548/1457]) of all differentially expressed mRNAs) and 219 pairs were positively correlated $(15.03 \%$ of all correlations). This network indicated that one lncRNA could correlate with one or tens of mRNA and different lncRNA correlated with the same mRNA. Moreover, this network could be used to predict target genes of these IncRNAs.

Five of seven qRT-PCR validated IncRNA could predict target mRNA. STAT3 is the target gene of lncRNA ENST00000570843.1 and STAT3 was downregulated according to microarray and qRT-PCR analysis. Many target mRNA of these lncRNA were downregulated (Additional file 10: Table S8).

\section{GO and pathway analyses}

GO analysis was performed to identify genes and measure gene product enrichment involved in biological processes, cellular components and molecular functions. We noted that significantly different transcripts between sub-lethally heat-treated HCC cells and untreated HCC cells were mainly associated with cellular process (ontology: biological process), binding (ontology: molecular function), and the cell component (ontology: cellular component) (Fig. 7, Additional file 11: Table S9). Pathway analysis indicated that 265 pathways corresponded to significantly different transcripts and that the most enriched network was "metabolic pathways," which was comprised of 108 targeted genes (Additional file 12: Table S10).

Target genes of significantly different lncRNAs assessed with GO indicated that these target genes were mainly associated with cellular process (ontology: biological process), binding (ontology: molecular function) and the cell (ontology: cellular component) (Fig. 8, Additional file 13: Table S11). Pathway analysis indicated that 142 pathways were associated with significantly

Table 2 Characteristics of qRT-PCR IncRNAs

\begin{tabular}{lllllll}
\hline IncRNA & Expression & Chromosome & Strand & Start & End & Class \\
\hline ENST00000570843.1(p5848) & Up & 16 & - & 3206736 & 3207484 & Intergenic \\
ENST00000567668.1(p5993) & Up & 16 & - & 33950098 & 33957115 & Intergenic \\
ENST00000582249.1(p7100) & Up & 17 & - & 80434472 & 80435800 & Antisense \\
TCONS_00015544(p24067) & Up & 8 & - & 144795187 & 144796371 & Intergenic \\
ENST00000602478.1(p11222) & Up & 22 & + & 43011249 & 43011913 & Intergenic \\
ENST00000450304.1(p16965) & Up & 9 & + & 139443581 & 139444345 & Antisense \\
TCONS_00001266(p17840) & Up & 1 & + & 212731195 & 212734165 & Intergenic \\
\hline
\end{tabular}


Table 3 Characteristics of qRT-PCR mRNAs

\begin{tabular}{|c|c|c|c|c|c|}
\hline mRNA & Expression & GenBank Accession & Gene name & Genomic coordinates & Cytoband \\
\hline ARC & Up & NM_015193 & $\begin{array}{l}\text { Activity-regulated cytoskeleton-associated } \\
\text { protein }\end{array}$ & chr8:143692638-143692579 & hs|8q24.3 \\
\hline IL12RB1 & Up & NM_153701 & Interleukin 12 receptor, beta 1 & chr19:18183032-18182973 & hs|19p13.11 \\
\hline HSPA6 & Up & NM_002155 & Heat shock 70 kDa protein 6 (HSP70B') & chr1:161495332-161495391 & hs|1q23.3 \\
\hline STAT3 & Down & NM_213662 & $\begin{array}{l}\text { Signal transducer and activator of transcription } 3 \\
\text { (acute-phase response factor) }\end{array}$ & chr17:40474463-40474404 & hs|17q21.2 \\
\hline PRPSAP1 & Down & NM_002766 & $\begin{array}{l}\text { Phosphoribosyl pyrophosphate synthetase-associated } \\
\text { protein } 1\end{array}$ & chr17:74307297-74307238 & hs|17q25.1 \\
\hline MCU & Down & NM_138357 & Mitochondrial calcium uniporter & chr10:74646758-74646817 & hs|10q22.1 \\
\hline URB2 & Down & NM_014777 & URB2 ribosome biogenesis 2 homolog (S. cerevisiae) & chr1:229795276-229795335 & hs|1q42.13 \\
\hline
\end{tabular}

different lncRNAs and again the most enriched network was "metabolic pathways," which was comprised of nine targeted genes (Additional file 14: Tables S12).

\section{Discussion}

RFA is commonly used for treating HCC and this usually produces a transition zone in which the temperature does not achieve therapeutic efficacy, so it is sub-lethal to these cells. These residual tumor cells can return and rapidly produce subsequent tumors, representing a significant drawback for RFA. Recently, research suggests that lncRNAs are important in complicated diseases such as cancer [22]. Several lncRNA have been identified as being involved in the development and progression of HCC, such as IncRNA-HEIH [23], HOTAIR [24, 25], lncRNA MVIH [26], IncRNA-Dreh [27], HOTTIP/HOXA13 [28, 29], URHC [30], PCNA-AS1 [31], UFC1 [32], HULC [33], CCAT1 [34], PVT1 [35], ANRIL [36, 37], ZEB1-AS1 [38], PANDAR [39], DANCR [40]. Some of these IncRNA were also identified in our microarray data. For example, PVT1 and DANCR were upregulated in sub-lethally heat-treated HCC cells. Research indicates that BC017743, ENST00000395084, NR_026591, NR_015378, and NR_024284 were upregulated, whereas NR_027151, AK056988, and uc003yqb.1 were down-regulated in HCC samples and adjacent nontumor tissues according to microarray analysis [17]. The relationship between lncRNAs and HCC cell invasion and metastasis was identified using the same method [18]. Long noncoding RNA expression in TGF- $\beta 2$-induced epithelialmesenchymal transition has been identified [41] and investigators have reviewed the important role for lncRNA in hepatitis B virus-induced liver cancer [42], but few studies exist to describe changes in lncRNA in sub-lethally heattreated HCC cells that recover after treatment.

Here, we report that $782 \operatorname{lncRNA}$ and 1281 mRNA were significantly differentially expressed compared to untreated SMMC-7721 cells. Bioinformatic analyses confirmed that differentially expressed lncRNAs and mRNAs using GO, as well as pathway and co-expression network analysis had value for target and transcript factor prediction. Subsequent analysis of hepatic-specific lncRNAs and validation of microarray results by qRTPCR were also performed. Data from GO and pathway analysis indicated that differentially expressed mRNAs and IncRNAs are related to metabolic pathways, indicating that metabolic pathways in sub-lethally heat-treated HCC cells undergo energy changes that allow adaptation and survival. We uploaded these data to the GEO web site (accession \# GSE99351).

We selected seven IncRNA and seven mRNA for qRTPCR analysis and these data are consistent with microarray data. But the mRNA expression is not the same in the three HCC cells, probably because different cell lines have different biological behaviors and expression profiles. Then, we constructed lncRNA-mRNA co-expression networks for seven lncRNAs. ENST00000570843.1 expression was the most changed, so in the future, we will study its role in proliferation and recurrence of residual cancer cells after RFA treatment.

We previously reported that RFA combined with sorafenib can prolong patient survival [43]. However, chemoresistance is common and influences patient prognosis. Here, we report [44] data for IncRNA expression in chemo-resistant HCC cells in which we identified 120 differentially expressed lncRNAs, of which 61 were upregulated and 59 were down-regulated. The underlying pathways of these differences in expression were related to cell death, proliferation, and cellular response to stimuli, and these included the p53, ErbB, and MAPK pathways. There is an interest in using lncRNAs as biomarkers of cancer as some investigators report that lncRNA expression data obtained with microarray from plasma of HCC and chronic hepatitis B patients had markers that may help diagnose HCC. Specifically, they identified lncRNAurothelial carcinoma associated-1 (ncRNA-UCA1) and WD repeat containing antisense to TP53 (WRAP53) as novel biomarkers for noninvasive diagnosis of HCC [45]. Serum expression of uc001ncr and AX800134 may also be a biomarker for diagnosing $\mathrm{HCC}$, especially for patients 


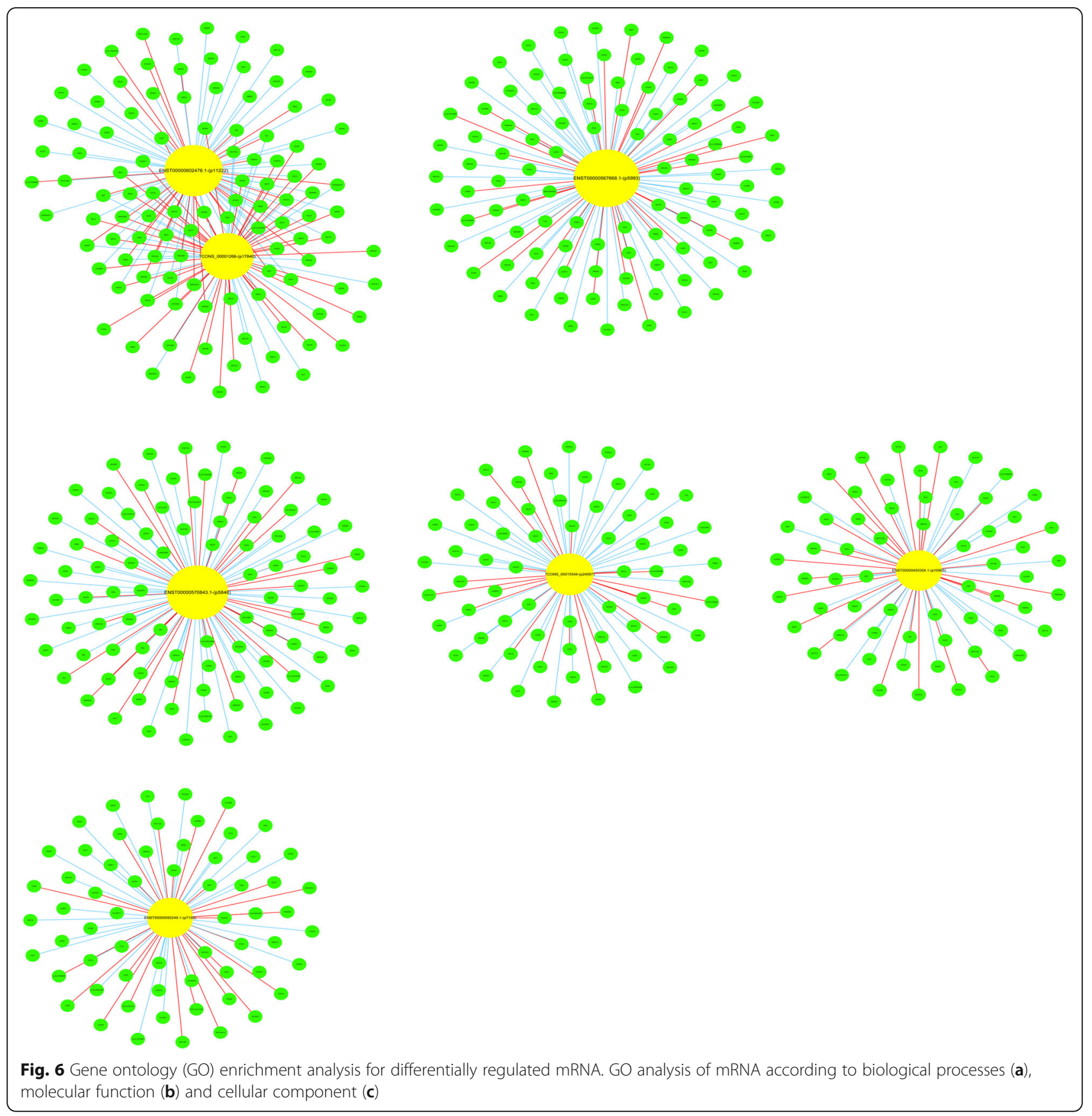

with AFP $\leq 400 \mathrm{ng} / \mathrm{ml}$ or with early-stage disease (BCLC $0+$ A) [46]. Thus, IncRNA may be novel therapeutic targets for cancer [47].

Our choice of $50{ }^{\circ} \mathrm{C}$ heat applied for 10 min was selected based on observations that this best simulated the RFA transition zone when treating HCC. Also, tumor cells did not die after this heat application but their proliferation and invasiveness was enhanced after culture. This may cause more rapid tumor recurrence compared to surgical resection. The timing of $10 \mathrm{~min}$ best approximates clinical RFA applications. Finally, this heat applied at this time did not kill all cancer cells, but they recovered after 3 weeks (data not shown). After application of $47^{\circ} \mathrm{C}$ for $10 \mathrm{~min}$, cancer cells did not have altered morphology and did not change significantly after a lengthy culture. Therefore, our temperature and duration of application may best replicate heat stress experienced by residual cancer cells in the RFA transition zone.

Study limitations include sub-lethal RFA and lncRNA expression measurements after a short interval. IncRNA expression changes may not occur this rapidly in clinical specimens. In addition, we could not obtain HCC tissue 

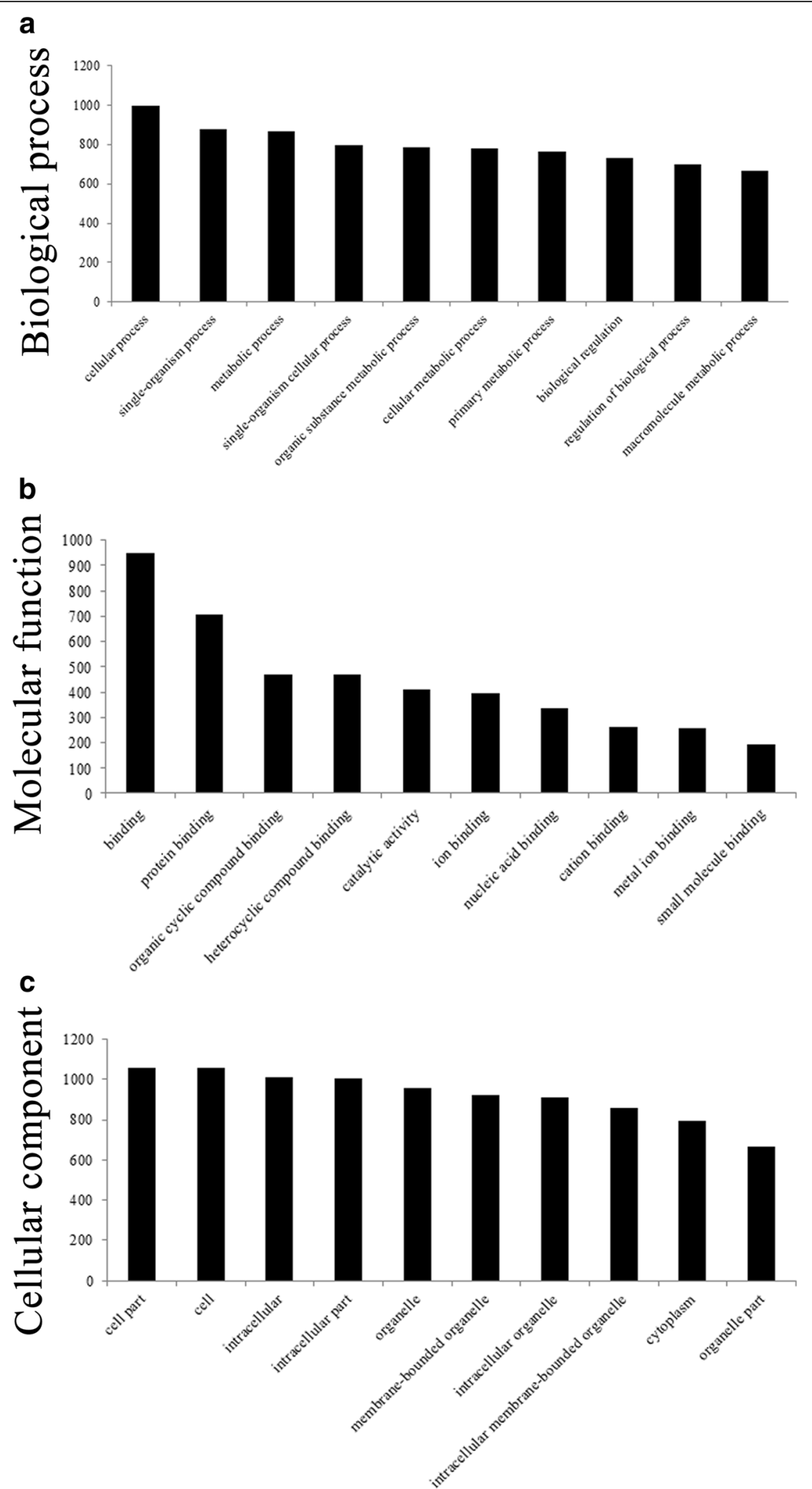

Fig. $7 \mathrm{GO}$ enrichment analysis for target genes of differentially regulated IncRNAs. GO analysis of mRNA according to biological processes (a), molecular function (b) and cellular component (c) 
a

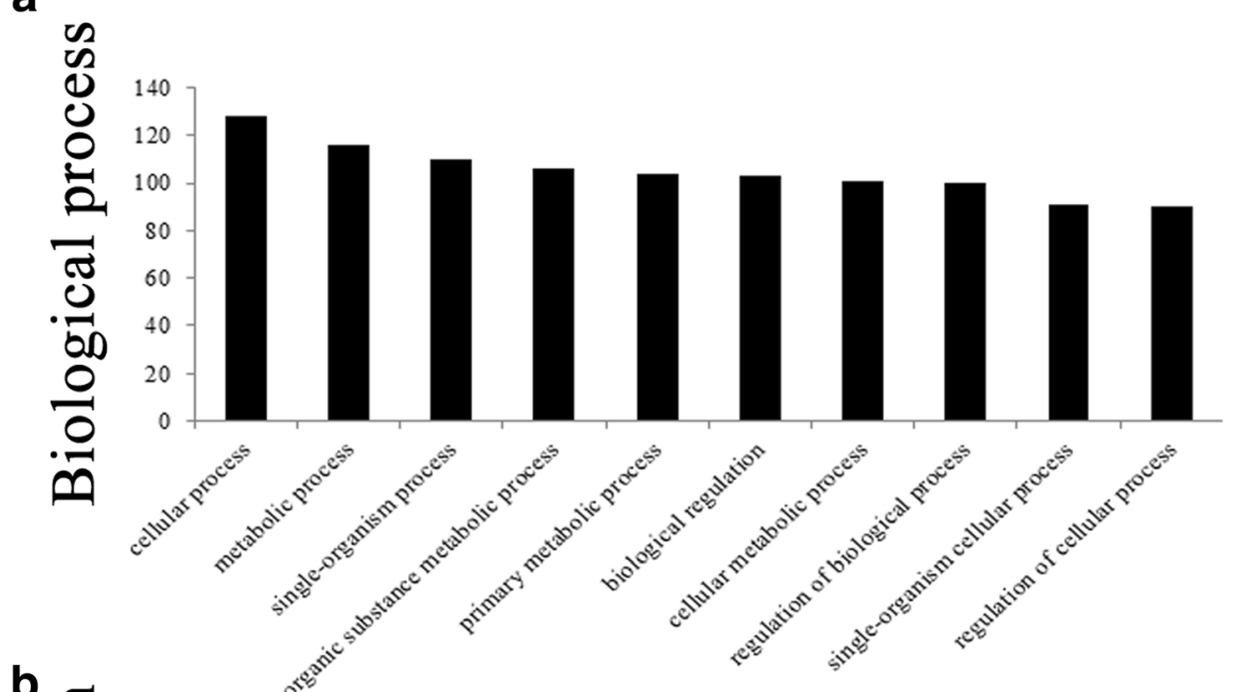

b
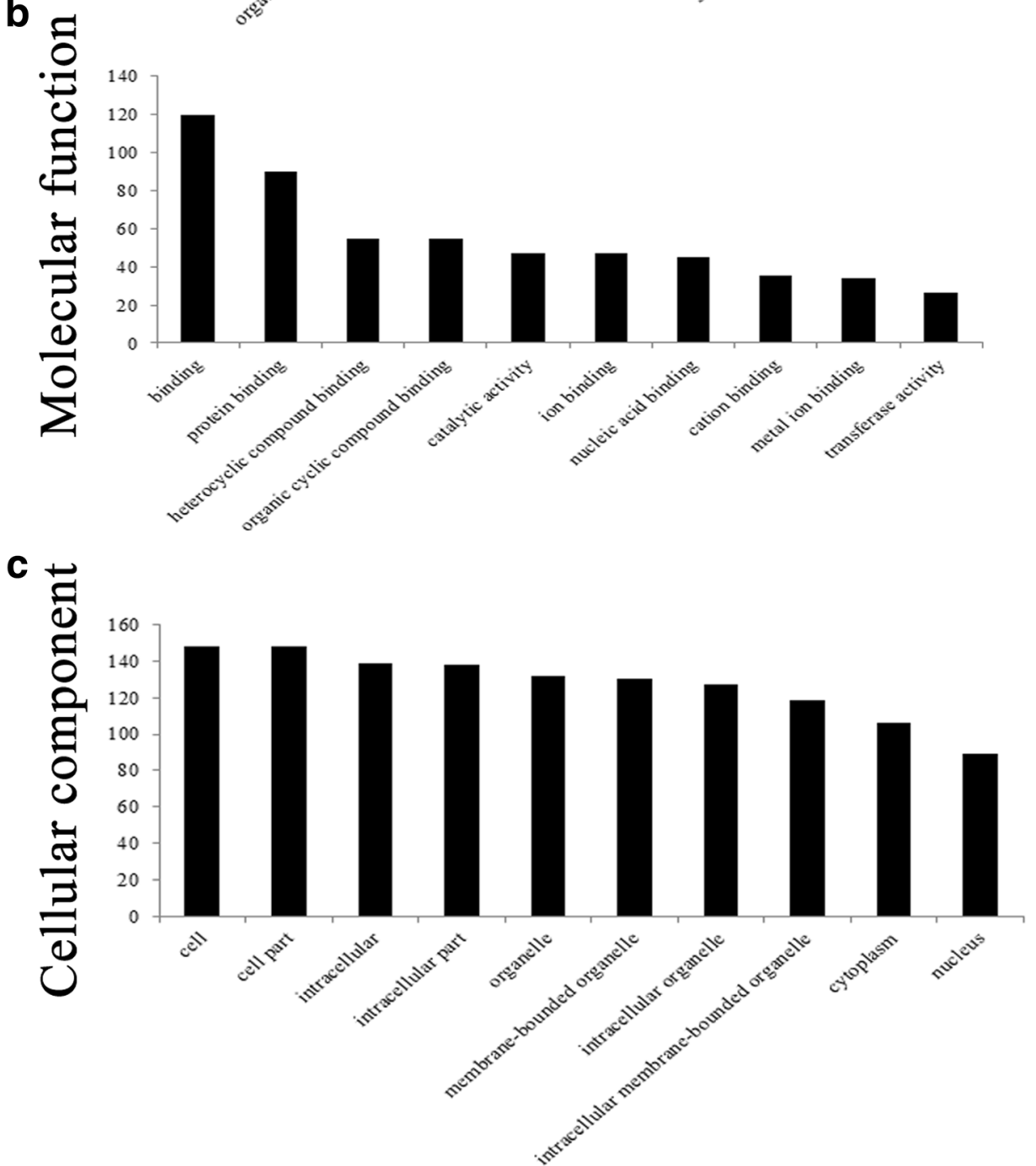

Fig. 8 GO enrichment analysis of target genes of differentially regulated IncRNAs. GO analysis of mRNA according to biological processes (a), molecular function (b) and cellular component (c) 
specimens during or after RFA treatment because HCC biopsies are controversial in our institution (rarely produced). Therefore, HCC tissue specimens were not used for microarray analysis. So, we will quantify ENST00000570843.1 in blood samples (see above). In summary, we described global expression profiles of lncRNAs and mRNAs in sub-lethally heat-treated HCC cells using lncRNA and mRNA microarrays. With bioinformatics predictions, we identified target genes that are correlated with differentiation of seven candidate lncRNAs. Further studies of functional analysis of these IncRNA are needed to provide more conclusive evidence about their regulatory mechanisms. Collectively, our results suggest that lncRNAs are important regulators of transition zone tumor recurrence and may guide further investigation into mechanisms of lncRNAs that regulate residual cancer cell return after RFA treatment.

\section{Conclusions}

In this study, we simulated the transition zone (area of residual cancer occurrence) of RFA with sub-lethal heat treatment of the cultured cells. We obtained long noncoding RNA expression profiles in sub-lethal heattreated hepatoma carcinoma cells. Our results provide theoretical support for residual cancer recurrence in the transition zone of RFA treatment. We provided new ideas for biological change of residual cancer cells.

\section{Additional files}

Additional file 1: Figure S1. RNA quality. (1) and (3): DL2000 Marker; (2): Normal cultured HCC cells(The first repeat experiment); (3): sub-lethally heat-treated HCC cells(The first repeat experiment); (4Normal cultured HCC cells(The second repeat experiment); (5sub-lethally heat-treated HCC cells(The second repeat experiment); (6) Normal cultured HCC cells(The third repeat experiment); ?] sub-lethally heat-treated HCC cells(The third repeat experiment); (TIF $1244 \mathrm{~kb}$ )

Additional file 2: Figure S2. CRNA amplification and labeling procedures (TIF $251 \mathrm{~kb}$ )

Additional file 3: Table S1. InCRNA qRT-PCR primers and product size. (DOCX $18 \mathrm{~kb}$ )

Additional file 4: Table S2. mRNA qRT-PCR primers and product size. (DOCX $17 \mathrm{~kb}$ )

Additional file 5: Table S3. Significantly differentially expressed IncRNAs and mRNAs. (XLS $2545 \mathrm{~kb}$ )

Additional file 6: Table S4. Classification and subgroup analysis of upregulated IncRNAs. (XLSX 206 kb)

Additional file 7: Table S5. Classification and subgroup analysis of downregulated IncRNAs. (XLSX $92 \mathrm{~kb}$ )

Additional file 8: Table S6. Liver specific IncRNA analysis. (XLSX 349 kb) Additional file 9: Table S7. Significant correlation of cytoscape network. (XLS $51 \mathrm{~kb}$ )

Additional file 10: Table S8. Target prediction summary. (XLS $2 \mathrm{~kb}$ )

Additional file 11: Table S9. N vs C GO enrichment. (XLSX $1980 \mathrm{~kb}$ )

Additional file 12: Table S10. N vs C pathway enrichment. (XLSX $351 \mathrm{~kb}$ ) Additional file 13: Table S11. Target $G O$ enrichment. (XLSX 443 kb)
Additional file 14: Table S12. Target pathway enrichment. (XLSX 107 kb)

\section{Abbreviations}

EMT: Epithelial-mesenchymal transition; HCC: Hepatocellular carcinoma; HIF-1a: Hypoxia inducible factor-1a; IncRNAs: Long noncoding RNAs; RFA: Radiofrequency ablation; VEGFA: Vascular endothelial growth factor A

\section{Acknowledgements}

Not applicable.

\section{Funding}

This work was supported by two grants from the Surface Project of the National Natural Science Foundation of the People's Republic of China (No. 81272688) and a Key Project of Application Development of Chongqing (No. cstc2014yykfB10002).

\section{Availability of data and materials}

Data sharing is not applicable to this article as no datasets were generated or analyzed during the current study.

\section{Authors' contributions}

QD and SC wrote the main manuscript text and supplementary information. CF and JJ prepared Figs. 1, 2 and 3. MZ and YT prepared Figs. 4, 5 and 6. XW and FX prepared Fig. 7 and KF and KM designed the experiment. PB directed the writing of the manuscript. All authors read and approved the final manuscript.

Ethics approval and consent to participate

Not applicable.

\section{Consent for publication}

Not applicable.

\section{Competing interests}

The authors declare that they have no competing interests.

\section{Publisher's Note}

Springer Nature remains neutral with regard to jurisdictional claims in published maps and institutional affiliations.

Received: 7 April 2017 Accepted: 22 June 2017

Published online: 21 July 2017

References

1. Torre LA, Bray F, Siegel RL, Ferlay J, Lortet-Tieulent J, Jemal A. Global cancer statistics, 2012. CA Cancer J Clin. 2015;65:87-108.

2. Curley SA, Izzo F, Delrio P, Ellis LM, Granchi J, Vallone P, et al. Radiofrequency Ablation of Unresec Primary and Metastatic Hepatic Malignancies: Results in 123 Patients. Ann Surg. 1999;230:1-8.

3. Huang J, Yan L, Cheng Z, Wu H, Du L, Wang J, et al. A randomized trial comparing radiofrequency ablation and surgical resection for HCC conforming to the Milan criteria. Ann Surg. 2010;252:903-12.

4. Feng K, Yan J, Li X, Xia F, Ma K, Wang S, et al. A randomized controlled trial of radiofrequency ablation and surgical resection in the treatment of small hepatocellular carcinoma. J Hepatol. 2012;57:794-802.

5. Heisterkamp J, van Hillegersberg R, Sinofsky E, IJzermans JN. HeatResistant Cylindrical Diffuser for Interstitial Laser Coagulation: Comparison With the Bare-Tip Fiber in a Porcine Liver Model. Lasers in Surgery and Medicine. 1997;20:304-9.

6. Obara K, Matsumoto N, Okamoto M, Kobayashi M, Ikeda H, Takahashi H, et al. Insufficient radiofrequency ablation therapy may induce further malignant transformation of hepatocellular carcinoma. Hepatol Int. 2008;2:116-23.

7. Ke S, Ding XM, Kong J, Gao J, Wang SH, Cheng Y, et al. Low temperature of radiofrequency ablation at the target sites can facilitate rapid progression of residual hepatic VX2 carcinoma. J Transl Med. 2010;8:73.

8. Hidehiro T, Tetsuo O, Yasuhiro S, Toshifumi W, Isamu M, Hironori H. Expression of epithelial-mesenchymal transition markers in locally recurrent hepatocellular carcinoma after radiofrequency ablation. Exp Ther Med. 2010;1:347-50. 
9. Dong S, Kong J, Kong F, Kong J, Gao J, Ke S, et al. Insufficient radiofrequency ablation promotes epithelial-mesenchymal transition of hepatocellular carcinoma cells through Akt and ERK signaling pathways. J Transl Med. 2013;11:273.

10. Yoshida S, Kornek M, Ikenaga N, Schmelzle M, Masuzaki R, Csizmadia E, et al. Sublethal heat treatment promotes epithelial-mesenchymal transition and enhances the malignant potential of hepatocellular carcinoma. Hepatology. 2013;58:1667-80.

11. Kong J, Kong L, Kong J, Ke S, Gao J, Ding X, et al. After insufficient radiofrequency ablation, tumor-associated endothelial cells exhibit enhanced angiogenesis and promote invasiveness of residual hepatocellular carcinoma. J Transl Med. 2012;10:230.

12. Kong J, Kong J, Pan B, Ke S, Dong S, Li X, et al. Insufficient Radiofrequency Ablation Promotes Angiogenesis of Residual Hepatocellular Carcinoma via HIF-1a/VEGFA. PLoS ONE. 2012;7:e37266.

13. Kroeze SG, van Melick HH, Nijkamp MW, Kruse FK, Kruijssen LW, van Diest PJ, et al. Incomplete thermal ablation stimulates proliferation of residual renal carcinoma cells in a translational murine model. BJU Int. 2012;110:E281-286.

14. Zhang N, Wang L, Chai ZT, Zhu ZM, Zhu XD, Ma DN, et al. Incomplete Radiofrequency Ablation Enhances Invasiveness and Metastasis of Residual Cancer of Hepatocellular Carcinoma Cell HCCLM3 via Activating betaCatenin Signaling. PLoS One. 2014;9:e115949.

15. Ponting $C P$, Oliver $P L$, Reik W. Evolution and functions of long noncoding RNAs. Cell. 2009;136:629-41.

16. Wang KC, Chang HY. Molecular mechanisms of long noncoding RNAs. Mol Cell. 2011;43:904-14.

17. Zhu J, Liu S, Ye F, Shen Y, Tie Y, Zhu J, et al. The Long Noncoding RNA Expression Profile of Hepatocellular Carcinoma Identified by Microarray Analysis. PLoS ONE. 2014;9:e101707

18. Gao Y, Chen G, Zeng Y, Zeng J, Lin M, Liu X, et al. Invasion and metastasisrelated long noncoding RNA expression profiles in hepatocellular carcinoma. Tumour Biol. 2015;36:7409-22.

19. Patterson TA, Lobenhofer EK, Fulmer-Smentek SB, Collins PJ, Chu TM, Bao $W$, et al. Performance comparison of one-color and two-color platforms within the MicroArray Quality Control (MAQC) project. Nat Biotechnol. 2006; 24:1140-50.

20. Barabasi AL, Oltvai ZN. Network biology: understanding the cell's functional organization. Nat Rev Genet. 2004;5:101-13.

21. Livak KJ, Schmittgen TD. Analysis of relative gene expression data using real-time quantitative PCR and the 2(-Delta Delta C(T)) Method. Methods. 2001;25:402-8

22. Gutschner T, Diederichs $\mathrm{S}$. The hallmarks of cancer: a long non-coding RNA point of view. RNA Biol. 2012;9:703-19.

23. Yang F, Zhang L, Huo XS, Yuan JH, Xu D, Yuan SX, et al. Long noncoding RNA high expression in hepatocellular carcinoma facilitates tumor growth through enhancer of zeste homolog 2 in humans. Hepatology. 2011;54: 1679-89.

24. Ding C, Cheng S, Yang Z, Lv Z, Xiao H, Du C, et al. Long non-coding RNA HOTAIR promotes cell migration and invasion via down-regulation of RNA binding motif protein 38 in hepatocellular carcinoma cells. Int J Mol Sci. 2014;15:4060-76.

25. Fu WM, Zhu X, Wang WM, Lu YF, Hu BG, Wang H, et al. Hotair mediates hepatocarcinogenesis through suppressing miRNA-218 expression and activating P14 and P16 signaling. J Hepatol. 2015;63:886-95.

26. Yuan SX, Yang F, Yang Y, Tao QF, Zhang J, Huang G, et al. Long noncoding RNA associated with microvascular invasion in hepatocellular carcinoma promotes angiogenesis and serves as a predictor for hepatocellular carcinoma patients' poor recurrence-free survival after hepatectomy. Hepatology. 2012;56:2231-41

27. Huang JF, Guo YJ, Zhao CX, Yuan SX, Wang Y, Tang GN, et al. Hepatitis B virus $X$ protein $(\mathrm{HBX})$-related long noncoding RNA (IncRNA) down-regulated expression by HBx (Dreh) inhibits hepatocellular carcinoma metastasis by targeting the intermediate filament protein vimentin. Hepatology. 2013;57: 1882-92.

28. Quagliata L, Matter MS, Piscuoglio S, Arabi L, Ruiz C, Procino A, et al. Long noncoding RNA HOTTIP/HOXA13 expression is associated with disease progression and predicts outcome in hepatocellular carcinoma patients. Hepatology. 2014;59:911-23.

29. Tsang FH, Au SL, Wei L, Fan DN, Lee JM, Wong CC, et al. Long non-coding RNA HOTTIP is frequently up-regulated in hepatocellular carcinoma and is targeted by tumour suppressive miR-125b. Liver Int. 2015;35:1597-606.
30. Xu WH, Zhang JB, Dang Z, Li X, Zhou T, Liu J, et al. Long non-coding RNA URHC regulates cell proliferation and apoptosis via ZAK through the ERK MAPK signaling pathway in hepatocellular carcinoma. Int J Biol Sci. 2014;10: 664-76.

31. Yuan SX, Tao QF, Wang J, Yang F, Liu L, Wang LL, et al. Antisense long noncoding RNA PCNA-AS1 promotes tumor growth by regulating proliferating cell nuclear antigen in hepatocellular carcinoma. Cancer Lett. 2014;349:8794.

32. Cao C, Sun J, Zhang D, Guo X, Xie L, Li X, et al. The long intergenic noncoding RNA UFC1, a target of MicroRNA 34a, interacts with the mRNA stabilizing protein HuR to increase levels of beta-catenin in HCC cells. Gastroenterology. 2015;148:415-26. e418.

33. Cui $M$, Xiao Z, Wang $Y$, Zheng $M$, Song $T$, Cai $X$, et al. Long noncoding RNA HULC modulates abnormal lipid metabolism in hepatoma cells through an miR-9-mediated RXRA signaling pathway. Cancer Res. 2015;75:846-57.

34. Deng L, Yang SB, Xu FF, Zhang JH. Long noncoding RNA CCAT1 promotes hepatocellular carcinoma progression by functioning as let-7 sponge. J Exp Clin Cancer Res. 2015;34:18.

35. Ding C, Yang Z, Lv Z, Du C, Xiao H, Peng C, et al. Long non-coding RNA PVT1 is associated with tumor progression and predicts recurrence in hepatocellular carcinoma patients. Oncol Lett. 2015;9:955-63.

36. Huang MD, Chen WM, Qi FZ, Xia R, Sun M, Xu TP, et al. Long non-coding RNA ANRIL is upregulated in hepatocellular carcinoma and regulates cell apoptosis by epigenetic silencing of KLF2. J Hematol Oncol. 2015;8:50.

37. Hua L, Wang CY, Yao KH, Chen JT, Zhang JJ, Ma WL. High expression of long non-coding RNA ANRIL is associated with poor prognosis in hepatocellular carcinoma. Int J Clin Exp Pathol. 2015;8:3076-82.

38. Li T, Xie J, Shen C, Cheng D, Shi Y, Wu Z, et al. Upregulation of long noncoding RNA ZEB1-AS1 promotes tumor metastasis and predicts poor prognosis in hepatocellular carcinoma. Oncogene. 2016;35:1575-84.

39. Peng W, Fan H. Long non-coding RNA PANDAR correlates with poor prognosis and promotes tumorigenesis in hepatocellular carcinoma. Biomed Pharmacother. 2015:72:113-8.

40. Yuan SX, Wang J, Yang F, Tao QF, Zhang J, Wang LL, et al. Long Noncoding RNA DANCR Increases Stemness Features of Hepatocellular Carcinoma by Derepression of CTNNB1. HEPATOLOGY. 2016;63:499-511.

41. Zhang B, Chen Y, Qiu M, Ding Z. Long noncoding RNA expression profile in HLE B-3 cells during TGF-beta2-induced epithelial-mesenchymal transition. BMC Ophthalmol. 2017;17:69.

42. Moyo B, Nicholson SA, Arbuthnot PB. The role of long non-coding RNAs in hepatitis B virus-related hepatocellular carcinoma. Virus Res. 2016;212:10313.

43. Feng X, Xu R, Du X, Dou K, Qin X, Xu J, et al. Combination therapy with sorafenib and radiofrequency ablation for BCLC Stage 0-B1 hepatocellular carcinoma: a multicenter retrospective cohort study. Am J Gastroenterol. 2014;109:1891-9.

44. Yin X, Zheng SS, Zhang L, Xie XY, Wang Y, Zhang BH, et al. Identification of long noncoding RNA expression profile in oxaliplatin-resistant hepatocellular carcinoma cells. Gene. 2017;596:53-88.

45. Kamel MM, Matboli M, Sallam M, Montasser IF, Saad AS, El-Tawdi AH. Investigation of long noncoding RNAs expression profile as potential serum biomarkers in patients with hepatocellular carcinoma. Transl Res. 2016;168: 134-45.

46. Wang K, Guo WX, Li N, Gao CF, Shi J, Tang YF, et al. Serum LncRNAs Profiles Serve as Novel Potential Biomarkers for the Diagnosis of HBV-Positive Hepatocellular Carcinoma. PLoS One. 2015;10:e0144934.

47. Lavorgna G, Vago R, Sarmini M, Montorsi F, Salonia A, Bellone M. Long noncoding RNAs as novel therapeutic targets in cancer. Pharmacol Res. 2016; 110:131-8. 